\title{
Community Voices, Practices, and Memories in Environmental Communication: Iliamna Lake Yup'ik Place Names, Alaska
}

\author{
Yoko Kugo
}

\section{INTRODUCTION}

In every culture and language, people use place names to refer to locations and to communicate information about these places with others. But how do people name a place, how do they identify the place in the landscape, and what is the significance of place names and stories about the places to the people? From an anthropological viewpoint, these questions prompt a researcher to consider how the use of language reflects understandings of landscapes through communication. Comprehending place names from insider (or community) perspectives contributes to the discipline of environmental communication by demonstrating that people share information about their environment through place names. Naming places and

Y. Kugo $(\bowtie)$

Arctic and Northern Studies, University of Alaska Fairbanks, Fairbanks, AK, USA

e-mail: ykugo@alaska.edu

(C) The Author(s) 2022

103

A. Sjölander-Lindqvist et al. (eds.), Anthropological Perspectives on Environmental Communication, Palgrave Studies in Anthropology of Sustainability, https://doi.org/10.1007/978-3-030-78040-1_5 
knowing these places supports residents' lifeways (traveling, fishing, hunting, gathering) and commemorates their family histories and wisdom people have passed down for many generations. People share their memories and oral traditions through place names and dialogues in their language and within their regions.

As in many Indigenous communities, Alaska Natives' cultural landscapes are inextricable from their identities. Cultural landscapes are a culmination of collective memory, personal experience, local histories, oral traditions, and place names that people have passed down within a cultural or regional group - this being one of many processes that aid in forming cultural identity (Andrews \& Zoe, 1997; Cogos et al., 2017; Stoffle et al., 1997). The concept of cultural landscape enriches our understanding of environmental communication because cultural groups have practiced their land use in the region for many generations. For instance, the Yup'ik people (hereafter Yupiit, the plural for Yup'ik persons) of Southwest Alaska, who live in isolated areas and often in relatively small societies, have formed intimate relationships with the landscape through time by observing and participating in oral traditions with family and community elders (Fienup-Riordan, 1990, 2017). Many Yup'ik place names relate to the conditions of the land features, directional information, and the personal and collective memories of the community members and their relatives (Fienup-Riordan, 1990; Rearden \& Fienup-Riordan, 2014; Salmon, 2014). These Yup'ik place names and narratives help the Yupiit define who they are as a people and as individuals, as well as their relationships to the environment.

In my previous fieldwork in Iliamna Lake communities, I discovered a cultural aspect of the people's relationship to the environment which I find crucial to environmental communication. Some Iliamna Lake Elders reported that when people harvest fish and animals, they thank these animals for giving themselves to people. To show respect, the people discard the bones of fish and animals in specific places in the water and in the ground (Kugo, 2014, pp. 180-181). Such oral traditions and practices concerning places involve an identity dimension, one which must be explored to gain a better understanding of Iliamna Lake Yup'ik environmental communication. This chapter explores how the study of place names contributes to environmental communication and anthropology, presenting stories of Iliamna Lake Yup'ik place names intertwined with their cultural ethics as the sustainability aspect of environmental communication. The term "environment" generally refers to earth, atmosphere, 
and physical locations. However, people often recognize environment as more than physical structures, such as the Southern Paiute people in North America, who see natural bridges as their ancestors' past (see Stoffle, chapter "Living Stone Bridges: Epistemological Divides in Heritage Environmental Communication" of this book). Many residents of Riddarhyttan in Sweden recognize that the land is contaminated, but wish to remain in the community because they have established relationships after living there for several generations (see Sjölander-Lindqvist, chapter "Arsenic Fields: Community Understandings of Risk, Place, and Landscape" of this book). Place names and stories of places prompt the Iliamna Lake residents to remember the landscape (physical locations) and their ancestors' voices and lessons (cultural practices), which are significant dimensions of environmental communication in the Iliamna Lake region.

\section{A Study of Iliamna Lake Yup'ik Place Names}

While building rapport with Iliamna Lake communities since 2012 and conducting literature reviews on this region, I learned that Iliamna Lake Yup'ik place names have rarely been recorded in the literature, in contrast with the over 200 Dena'ina place names in the Iliamna Lake region that have been published (Evanoff, 2010; Kari, 2013). Archaeological data and Russian explorers' records suggest that the language groups of Dena'ina Athabascan (Na Dené) and Central Yup'ik (Eskaleut) have lived in the region at least since the eighteenth century (Townsend, 1973; VanStone, 1988; Wrangell \& VanStone, 1970). My dissertation project, a study of Iliamna Lake Yup'ik place names from 2016 to 2019, began with community members' request that I help them record and maintain Yup'ik place names and local histories about these places. The communities of Iliamna, Newhalen, Kokhanok, and Igiugig in the Iliamna Lake area and Levelock on the shore of the Kvichak River collaborated in the place names project that also served as my Ph.D. dissertation research. One Iliamna Lake resident told me that he wished they had begun this project when there were more Elders, "the original Googles," in the community (Iliamna Lake resident, pers. comm., Aug. 2016). Over 30 Elders, or those "original Googles," and community assistants in the five Iliamna Lake communities participated in eight ethnographic field trips between 2016 and 2019. 
Iliamna Lake lies about $362 \mathrm{~km}$ southwest of Anchorage, in southwest Alaska. Today, five communities lie on the shore of the lake: Pedro Bay, Iliamna, Newhalen, Kokhanok, and Igiugig. Levelock, a community on the Kvichak River, has close ties to the Iliamna Lake communities. The residents of Levelock have long traveled to the Iliamna Lake communities to visit and exchange goods. The Kvichak River (approximately $120 \mathrm{~km}$ long) drains Iliamna Lake to Bristol Bay, which hosts the largest run of sockeye salmon returning to Iliamna Lake and its tributaries for spawning every summer. According to several Iliamna Lake Yup'ik Elders, their families came from the Kwethluk area on the Kuskokwim River to the presentday Newhalen area looking for food during a time of high starvation in the mid-nineteenth century (Coffing, 1991; Iliamna Lake Place Names Workshop, May 16, 2018). Owing to traveling, migration, and intermarriage, the Iliamna Lake communities include descendants of Dena'ina, Central Yup'ik, Alutiiq, Russian, and northern European people. Iliamna Lake Yup'ik Elders have heard that Russian and Euro-American explorers and surveyors borrowed or replaced original Yup'ik names and renamed them in Russian or English when they came to the area in the past. The recounting of the original Indigenous place names and stories about these places represents, according to Smith (1999), a decolonizing process. This is further illustrated by the fact that many Yup'ik place names and stories of places cannot be translated into other languages, or these translated names do not tell a deeper meaning of the names, especially stories about family histories and personal memories.

During the first year of my fieldwork, I discovered that some Iliamna Lake Yup'ik place names have multiple meanings or are embedded in stories that originated with individuals' experiences and memories. To gain insider perspectives for myself (an outsider) and to share local voices with residents, the village and tribal councils of Iliamna Lake communities and I established the Iliamna Lake Place Names Committee in December 2017. We held the Iliamna Lake Place Names Workshop in Newhalen in May 2018 to review many place names and locations of these places. As a result, our project recorded 219 Yup'ik and over 150 contemporary English names. To distribute our results to community members, we published two styles of place name maps, printing textile maps ${ }^{1}$ for about 400

1 "Place Names of Iliamna Lake, Nanvarpak, Nila Vena" (Nielsen et al., 2019). 
residents and large paper maps ${ }^{2}$ for research participants, local council offices, and schools. Iliamna Lake Yup'ik Elders, schools, and village/ tribal councils obtained this large map for future projects and place-based education in their communities.

\section{Place Names as Environmental Communication}

People name places for various reasons, such as describing, honoring figures, commemorating historical events, narrating incidents, and adapting names through time, or their folk etymology. They share visual, directional, and historical information about these places through several forms of communication, including storytelling and participation in activities. Indigenous place names closely relate to insiders' use of language and oral narratives about these places within specific Indigenous cultures, from their own perspectives (Collignon, 2004; Cruikshank, 1990; Fair, 1997; Holton, 2011; Hunn, 2006; Kari, 1988; Ray, 1971; Rosaldo, 1980; Stewart, 1954; Thornton, 2008; Waterman, 1922). Such place names exemplify the Sapir-Whorf hypothesis that language, thoughts, and culture are deeply interconnected, and that the language people speak influences how they perceive their surroundings and conceive their own distinctive worldviews (Kluckhohn, 1961). Gumperz and Levinson (1996) reexamine the theory that such interconnected relationships with language differ among cultures and individuals, and that researchers should therefore address how language, thinking, and society are intertwined.

For instance, Basso (1988, 1996) discovered that Western Apache place names provide the people with mental advice, such as producing a mental image of a specific place, speaking about their ancestors, confirming their cultural values and morals, and/or offering comfort from being lost or stressed. The Western Apache also learn to "travel in [their] mind," so they can imagine the routes and feel confident about reaching these places (Basso, 1988, p. 123). While doing these tasks, Western Apache feel grateful for the help their ancestors' wisdom provides as they remember their ancestors and imagine their ancestors assisting them in traveling to the places. Western Apache place name practices represent environmental communication, as the Apache communicate with their ancestors, which help them to imagine the landscape physically and spiritually.

\footnotetext{
2 "Place Names of Nanvarpak, Nila Vena, Iliamna Lake" (Kugo \& Iliamna Lake Place Names Committee, 2019).
} 
Kawagley's (2006) introduction to a Yup'ik worldview reflects environmental communication. The Yupiit not only communicate with the visible environment, but they also include the thoughts and feelings of humans, animals, and natural forces that represent parts of the surroundings. By sensing, hearing, and smelling the air outside, Yupiit become aware that Ellam Yua (the Spirit of the Universe) is watching over and providing for them to live on the land (Fienup-Riordan, 1990; Fienup-Riordan \& Rearden, 2012; Kawagley, 2006). According to Kawagley (2006, p. 11), the Yupiit understand that "the land is a giver of life" by recognizing the oral tradition that the people were created and emerged in the YukonKuskokwim region. In a Yup'ik worldview, people interact reciprocally with the natural or spiritual realms. In harvesting resources from their homeland, the Yupiit have a duty to care for the land. They fulfill this responsibility by taking care of harvested animals and deceased humans in ethical ways so that the spirits of the animals and people will return to the living world. The Yupiit discard the bones of harvested animals into the water or in the ground after they consume the meat and bone marrow. To show their gratitude to these people, the animals will be reborn and return to be killed by the same hunters. Fienup-Riordan (1990) describes how the Yupiit perceive "the relationship between humans and animals as collaborative reciprocity: the animals gave themselves to the hunter in response to his respectful treatment of them as persons in their own right" (p. 72). Such cultural ethics signify Yup'ik environmental communication in the Yukon-Kuskokwim region.

Researchers define the notion of environmental communication in multiple ways. Cox (2007) emphasizes preserving biodiversity as a central component of environmental communication that is vital in many cases. Environmental communication often lacks the spirituality and intimate relationships that local and Indigenous people have practiced in their homeland. Senecah (2007) points out that people being willing to engage each other about environmental concerns is essential to environmental communication. In her notion, environmental communication includes respect for local and Indigenous knowledge and the understanding of holistic ecological systems (Senecah, 2007, p. 28). Place names can be tools for such environmental communication because the knowledge they contain persists within the practices, memories, and social dimensions that community members use to nourish an intimate relationship with their environment (Cogos et al., 2017). This creates a sense of guardianship, because the land is a part of their community. In such cases, literal 
translations of Indigenous place names rarely describe a holistic community understanding of the environment. Yupiit did not name the Iliamna Lake Yup'ik stream Quarrungvik ("Place with Stickleback"), near presentday Igiugig, after its land feature of stream, or kuik (river). Rather, they named the place in recognition of their local knowledge of ecosystems, referring to stickleback (Gasterosteus aculeatus), a species of fish. People generally do not fish for small sticklebacks for food, but they know that the stream is a good feeding place for larger fish because of the presence of sticklebacks. Igiugig residents who live near the stream know that the mouth of the stream is a good place for ice fishing (pers. comm., May 2016). Local knowledge-knowing the abundance of fish in the stream and its Indigenous place name-and preserving this knowledge through communication assists the people in maintaining biodiversity.

In his essay "Environmental Communication: What It Is and Why It Matters," Mark Meisner (n.d.) defines "environmental communication" as "communication about environmental affairs." Meisner identifies two broad social functions of environmental communication: people use communication to do things, and communication shapes how people perceive and create meanings within their surroundings. Place names and stories about these places often offer people geographic information about the land, which allows them to practice their traditional lifeways and care for the land, which ultimately affirms the connections between the people and their ancestors who have passed down their wisdom to future generations.

Meisner (n.d.), and Stoffle, Arnold, and Bulletts (2016) also discuss how Indigenous people and government natural resource managers communicate with the environment differently. Stoffle, Arnold, and Bulletts (2016) explain that the Southern Paiute people perceive the world, plants, animals, and minerals as a living universe that is sentient, similar to humans. Scientists and natural resource managers rely on scientific evidence, such as changes in animal populations and mineral density in the soil, to manage environmental resources (Nadasdy 2005; Stoffle et al., 2016; Ross et al. 2011). In contrast, the Southern Paiute people have passed down their cultural ethics to communicate with plants, animals, crystals, and minerals to maintain a healthful environment (Stoffle et al., 2016). While environmental activists use communication power in furtherance of their environmental values, as they challenge government plans for creating dams, pipelines, and other land development for national economic growth (Harris, 2017), Indigenous communities, such as the Southern 
Paiute and the Yukon-Kuskokwim Yupiit, communicate with the environment in fulfillment of their responsibility to maintain the relationships between animals, plants, land, spiritual beings, and people (FienupRiordan, 1990; Kawagley 2006; Stoffle et al., 2016). Environmental movements have emerged to protect the Earth's ecological system from human activity and global economy, but these movements typically reflect Western, rather than Indigenous orientations to the land. Yet Harris (2017, p. 77) points out that "local knowledge" is an effective means of environmental communication. As local knowledge is restricted to specific regions, Indigenous knowledge has been transmitted through an extended social system (e.g. from uncle to nephew) and practices as generations of Indigenous peoples have taught young people morals and ethics to live in harmony with their environments (Battiste \& Henderson, 2000; Berkes \& Folke, 1998). Similarly, place-naming practices are culturally and often locally unique, because they originate from oral information about personal and multi-generational experiences conveyed through native tongues and dialects. Collignon (2004) and Hunn (2006) call Indigenous place names "vernacular knowledge" that comprises observations of places and territories, and experiences in places, cumulatively shared by members of cultural groups. Indigenous place names, especially those in specific and regional languages, allow communication with the environment and the sharing of knowledge with limited groups-family and community members.

\section{Colonizing and Decolonizing Iliamna Lake Names}

The origins of Indigenous place names have often been obscured or reinterpreted as explorers and new settlers of lands have renamed places. After their arrival in Alaska in the mid-eighteenth century, Russian and EuroAmerican explorers recorded geographic information, including Native place names and new Russian and English place names, to expand trading routes with Alaska Natives and exploit natural resources on the land. Indigenous peoples orally shared their landscape information with others when traveling and telling stories about these places. For instance, Russian fur traders named Iliamna Lake in several ways, including $\mathrm{Oz}[\mathrm{ero}]$ Shelekhovo (lit. "lake Shelekov") to honor a political figure ${ }^{3}$ in 1786 ,

\footnotetext{
${ }^{3}$ Grigori Ivanovich Shelikov (Shelekov) was a founder of the Shelikhov-Golikov Company (later re-established as the Russian American Company), which first established a fur-trading
} 
Ilyamna in 1796, Lac Ilima (lit. "big lake," its name in French) in 1827, and Ozpo Ilima and $\mathrm{Oz}[\mathrm{ero}]$ Bol[shoy] Ilyamna (lit. "big Ilyamna lake" in Russian) in about 1850 (Orth, 1967, p. 449; Marvin Falk, email to the author, March 25, 2020). The Russian name Ilyamna is a distortion of the Dena'ina name Nila Vena. ${ }^{4}$ Held by the Russian Military Archive, the map created by Russian explorers Izmailov and Bocharov, dated 1785-1786, is one of the earliest maps that labels Iliamna Lake as "lake Shelekov." The map in Fig. I shows Iliamna Lake's Indigenous names as Nila Vena ("Islands Lake") in Dena'ina and Nanvarpak ("Big Lake") in Yugcetun (Evanoff, 2010; Igiugig Village Council, 2012; Krauss et al., 2011).

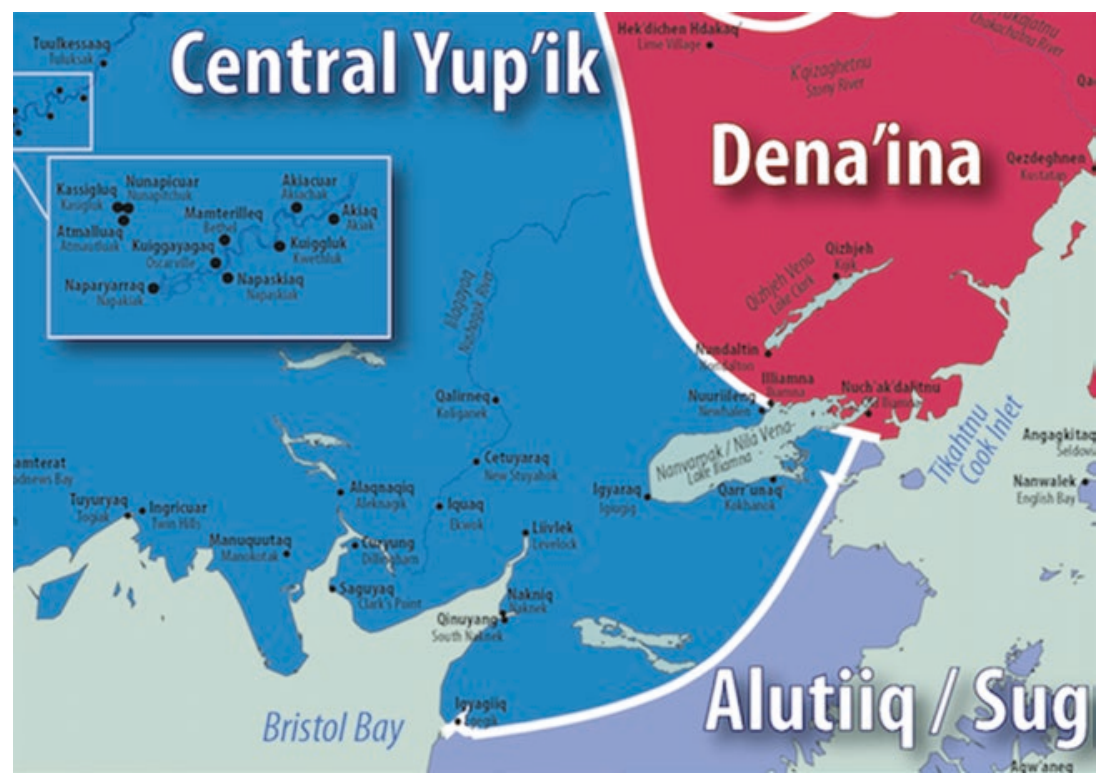

Fig. 1 Map of the area the author studied. Based on Krauss et al., 2011. (Image used courtesy of ANLC)

post on Kodiak Island around 1784. The Russian government later approved the RAC company's fur-trading monopoly, aiming to gain control over the land and people of RussianAmerica (Alaska) (Black, 2004, pp. 107, 255).

${ }^{4}$ According to some Iliamna Lake Elders, the present-day name "Iliamna" originated from the sound of its Dena'ina name, Nila Vena. 
Iliamna Lake is the largest freshwater lake in Alaska, and it contains many small islands, especially in the northeast part of the lake, where the Dena'ina traditionally settled. Iliamna Lake Yup'ik Elders remember that some Dena'ina place names near the language boundary on the northeast side of the lake have been "Yupified," or borrowed and adapted to resemble Yup'ik phonology (Iliamna Lake Place Names Workshop, May 15, 2018). Recording and decolonizing Indigenous place names restores local histories and recognizes local observations and interactions with the landscape.

To better comprehend Iliamna Lake Yup'ik place names from insider perspectives, I used two methods: qualitative interviewing as used by oral historians, and a community-based participatory approach to gather ethnographic data. A community-based participatory approach prompts researchers and study communities to develop the research design collaboratively, thereby benefiting both parties. Working with community research assistants and Yup'ik Elders, I explored how the Iliamna Lake Yupiit communicate with others about the landscape. In the next section, I present some place names as examples of environmental communication. I discuss how the Yupiit speak and convey knowledge of places through these names and how they commemorate relationships between people and the environment, in the past and in the present.

\section{Telling About Places}

Naming a place with a general term is a common practice in the Iliamna Lake region and across other regions and languages. Iliamna Lake Yupiit use generic land feature terms, such as ingriq (mountain), tevyaraq (portage), qikertaq (island), kuik (river), nanvaq (lake), and igcenaq (falling place or waterfall), to describe the shape and size of places. The place names in Table 1 below also use generic terms or common names such as Cunkvalek ("Place with Pike"). Hearing of such place names often confused me initially, because I was not familiar with the landscape from their vantage points or memories, and therefore did not understand to which lake, river, or portage they referred to.

For instance, I recorded at least five Cunkvaleks and five place names that related to cunkvaq, ${ }^{5}$ or northern pike (Esox Lucius). One of the lakes

5Jacobson's Yup'ik dictionary defines cunkvak as "northern pike" (2012, p. 234). Northern pike (Esox lucius) is a species of carnivorous freshwater fish found in the Northern Hemisphere, including Alaska. 
Table 1 Examples of Iliamna Lake place names, telling of places

\begin{tabular}{|c|c|c|c|c|}
\hline rup'ik name & $\begin{array}{l}\text { English } \\
\text { translation }\end{array}$ & $\begin{array}{l}\text { Narrators' } \\
\text { descriptions of } \\
\text { places } \\
\text { (Ethnographic } \\
\text { interview records } \\
\text { compiled from } \\
\text { my dissertation } \\
\text { project between } \\
2016 \text { and 2019) }\end{array}$ & English name & Location \\
\hline Cuukvalek & $\begin{array}{l}\text { "Place with } \\
\text { Pike" }\end{array}$ & $\begin{array}{l}\text { Pike fishing } \\
\text { place }\end{array}$ & $\begin{array}{l}\text { Schoolhouse Lake } \\
\text { (named after the } \\
\text { government built } \\
\text { the school) }\end{array}$ & $\begin{array}{l}\text { A lake near } \\
\text { present-day } \\
\text { Newhalen }\end{array}$ \\
\hline Igceńaq & $\begin{array}{l}\text { "Falling Place, } \\
\text { Waterfall" }\end{array}$ & $\begin{array}{l}\text { Falling place, } \\
\text { historical } \\
\text { accident at the } \\
\text { place }\end{array}$ & Rapids & $\begin{array}{l}\text { A fast-running } \\
\text { stretch of the } \\
\text { Newhalen River }\end{array}$ \\
\hline Tevyaraq & "Portage" & $\begin{array}{l}\text { Portage that } \\
\text { goes from the } \\
\text { lakeshore to the } \\
\text { mountain }\end{array}$ & $\begin{array}{l}\text { Roadhouse } \\
\text { Mountain (named } \\
\text { after a settler who } \\
\text { built the roadhouse) }\end{array}$ & $\begin{array}{l}\text { A mountain } \\
\text { near present-day } \\
\text { Iliamna }\end{array}$ \\
\hline Amartetuli & $\begin{array}{l}\text { "Customarily } \\
\text { Packed" }\end{array}$ & $\begin{array}{l}\text { Traditional } \\
\text { seasonal } \\
\text { campsite }\end{array}$ & $\begin{array}{l}\text { Amakdedori } \\
\text { (borrowing the } \\
\text { Yup'ik name) }\end{array}$ & $\begin{array}{l}\text { A historical site } \\
\text { on the Kamishak } \\
\text { Bay (a trail leads } \\
\text { here from the } \\
\text { Kokhanok area) }\end{array}$ \\
\hline Tagyaracuar & $\begin{array}{l}\text { "Small Place } \\
\text { to Go Up" }\end{array}$ & $\begin{array}{l}\text { Movement of } \\
\text { walking on the } \\
\text { trail }\end{array}$ & $\begin{array}{l}\text { Pope Vannoy } \\
\text { (named after the } \\
\text { settler's surname) }\end{array}$ & $\begin{array}{l}\text { A trail and site } \\
\text { on the south } \\
\text { side of Iliamna } \\
\text { Lake }\end{array}$ \\
\hline Kanaqlak & "Muskrat" & $\begin{array}{l}\text { Traditional } \\
\text { muskrat trapping } \\
\text { place }\end{array}$ & $\begin{array}{l}\text { Skater Lake } \\
\text { (contemporary } \\
\text { activity) }\end{array}$ & $\begin{array}{l}\text { A lake near } \\
\text { present-day } \\
\text { Igiugig }\end{array}$ \\
\hline
\end{tabular}


Table 1 (continued)

\begin{tabular}{|c|c|c|c|c|}
\hline Yup'ik name & $\begin{array}{l}\text { English } \\
\text { translation }\end{array}$ & $\begin{array}{l}\text { Narrators' } \\
\text { descriptions of } \\
\text { places } \\
\text { (Ethnographic } \\
\text { interview records } \\
\text { compiled from } \\
\text { my dissertation } \\
\text { project between } \\
2016 \text { and 2019) }\end{array}$ & English name & Location \\
\hline $\begin{array}{l}\text { Cunkvagpalgem } \\
\text { Kuiga, Olem } \\
\text { Kuiga }\end{array}$ & $\begin{array}{l}\text { "Big Pike's } \\
\text { Creek",“Ole's } \\
\text { River" }\end{array}$ & $\begin{array}{l}\text { Observed large } \\
\text { pike, settler's } \\
\text { cabin on the } \\
\text { shore of the } \\
\text { stream }\end{array}$ & $\begin{array}{l}\text { Ole Creek (named } \\
\text { after the settler) }\end{array}$ & $\begin{array}{l}\text { A stream to the } \\
\text { south of Iliamna } \\
\text { Lake }\end{array}$ \\
\hline Peksussurvik & $\begin{array}{l}\text { "Place to } \\
\text { Hunt Eggs" }\end{array}$ & $\begin{array}{l}\text { Seasonal seagull } \\
\text { hunting place }\end{array}$ & $\begin{array}{l}\text { Egg Island (English } \\
\text { translation of the } \\
\text { Yup'ik name) }\end{array}$ & $\begin{array}{l}\text { An island on the } \\
\text { Kvichak River }\end{array}$ \\
\hline
\end{tabular}

named Cuukvalek lies near present-day Newhalen and is known in English as Schoolhouse Lake, since the government built a school near the lake in the early twentieth century. When I listened to the Elders' stories, I came to understand that the Yupiit named places after their geographic features (Igcenaq and Tevyaraq) and that stories about these places often convey meaningful information about these locations. The Yupiit also named places after their harvesting activities (Cunkvalek, Kanaqlak, Cuukvagpalgem Kuiga, and Peksussurvik), local histories (Amartetuli and Tagyaracuar), and observations of newcomers (Olem Kuiga and Pope Vannoy, the English name of Tagyaracuar). The English name Amakdedori originated from the sound of the Yup'ik name Amartetuli ("Customarily Packed"). Amartetuli is a historical settlement that sits on the shore of Kamishak Bay in Cook Inlet on Alaska's Southcentral Coast. People used to walk on multiple trails between the Kokhanok area, which lies roughly at the midpoint of the southern shore of Iliamna Lake, and Amartetuli (Amakdedori). Through stories, Yup'ik Elders remember the places where the people used to pack babies and supplies when they walked to Amartetuli in springtime, but this English name does not explain the meaning of the place. Stories of place names prompt the Iliamna Lake 
Yupiit to remember historical events at these places and feelings toward the places and their locations.

Oral narratives of Igcenaq ("Falling Place" or "Waterfall"), one of the older Yup'ik settlements on the Newhalen River, demonstrate how Newhalen Yup'ik Elders understand the site as a fishing place, with Newhalen Yupiit family histories urging special caution because a person once drowned there (Fig. 2).

According to several Iliamna Lake Elders, their families who came from the Kuskokwim River to the Newhalen area settled and moved to three settlements prior to today's Newhalen location at the Newhalen River's mouth (Iliamna Lake Place Names Workshop, May 16, 2018; Kugo, 2014). Newhalen Yup'ik Elders remember the story of the Yupiit settling at and then abandoning a site along the Newhalen River called Igcenaq (Newhalen Elders, multiple personal communications, 2016, 2017, 2018). Newhalen Elder Annie Parks remembers that her father's family lived on the shore of Igcenaq before he married. She told of her father's oldest brother trying to spear a fish, and accidently falling into the rapids and being swept away. They never discovered his body.

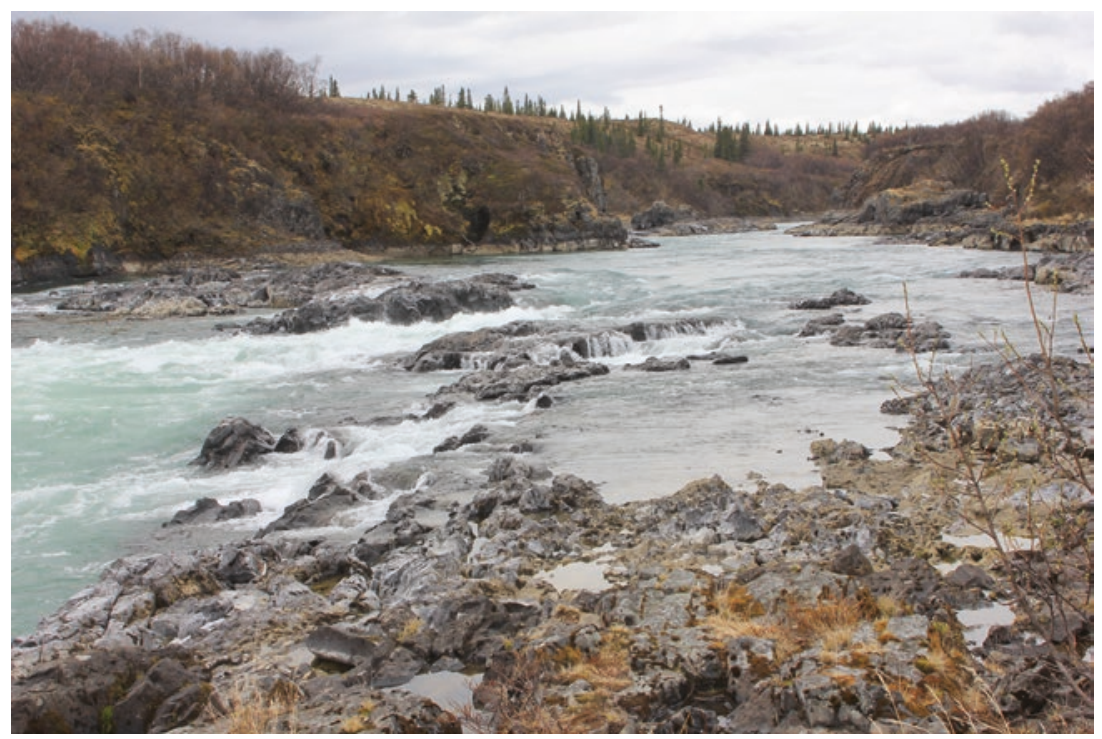

Fig. 2 Igcenaq on the Newhalen River, May 2018. (Photo: Yoko Kugo) 
They used to put up fish [up there]. They don't fish [...] they don't seine or [...] just use aggsumn (harpoon) like this, then they catch fish. One day, [he] was fishing, that he happened to fall. Igcenaq [...] doesn't come back, just fall. [...] And they couldn't find a body. [...] We got to move out of there from that Igcenaq. (Annie Parks, interview, August 24, 2016)

Parks's parents were concerned about their future children falling into the rapids. For that reason, after this accident, they moved to another location near present-day Newhalen. While she was telling the story about Igcenaq, Parks continued to tell of other people moving downriver from the original Igcenaq. Fienup-Riordan explains that such sharing of personal knowledge, "either direct or transmitted by persons to whom living men and women can trace a relationship" refers to a qanemciq, a historical account in the local environment (Fienup-Riordan, 1990, pp. 103, 244). Telling a narrative about Igcenaq triggered Parks's memories of how her family lived in a harsh environment and their migration history.

When Parks tells a qanemciq, she always begins with a phrase "I only tell you what I know." This expression of hers emphasizes that she gained her knowledge about her family history and homeland by listening to stories from her relatives who witnessed events. She has established intimate relationships with her family and homeland throughout her lifetime. Parks showed me the trails where her grandmother walked to three lakes near the present-day Iliamna Airport to catch pike. Parks's story implies spatial information about the environment, the location of a Yup'ik settlement near Igcenaq, and temporal information that existed approximately three generations ago.

Basso (1996) uses the term "place-making" to refer to "a way of constructing history itself” (p. 6). Parks's story about Igcenaq exemplifies "place-making" in that Parks remembers her family history that she learned from her mother, as well as her own observation of the land. I did not record stories describing other waterfalls called Igcenaq as dangerous places; rather they are pleasant places to hike or swim. Parks's story about Igcenaq on the Newhalen River illustrates that stories of place names carry meaning to residents, in this case, to be aware of the danger at this great place for fishing. 


\section{Cultural Practices and Places}

Telling of Yup'ik place names often prompted Elders to speak about their travel experiences and cultural ethics at these places. Iliamna Lake residents have transmitted such local knowledge through using place names in practices and activities such as navigation. According to Iliamna Lake Yup'ik Elders, many accidents occurred near Qikertarpak ("Big Island") in the southwest part of Iliamna Lake. When they tell stories about the accidents, they often include a story of gift-offering to the boulders, Kass'arnayiit ("Those That Look Like Priests"), which sit in the lake near Ingrirpak ("Big Mountain," Fig. 3). Some Iliamna Lake Yup'ik Elders reported that they make offerings by tossing food or pieces of crackers in the water when they go by Kass'aruayiit. By feeding Kass'aruayiit, the people will receive "good weather," according to Parks. Newhalen and Kokhanok residents must cross this area to reach the Kvichak River.

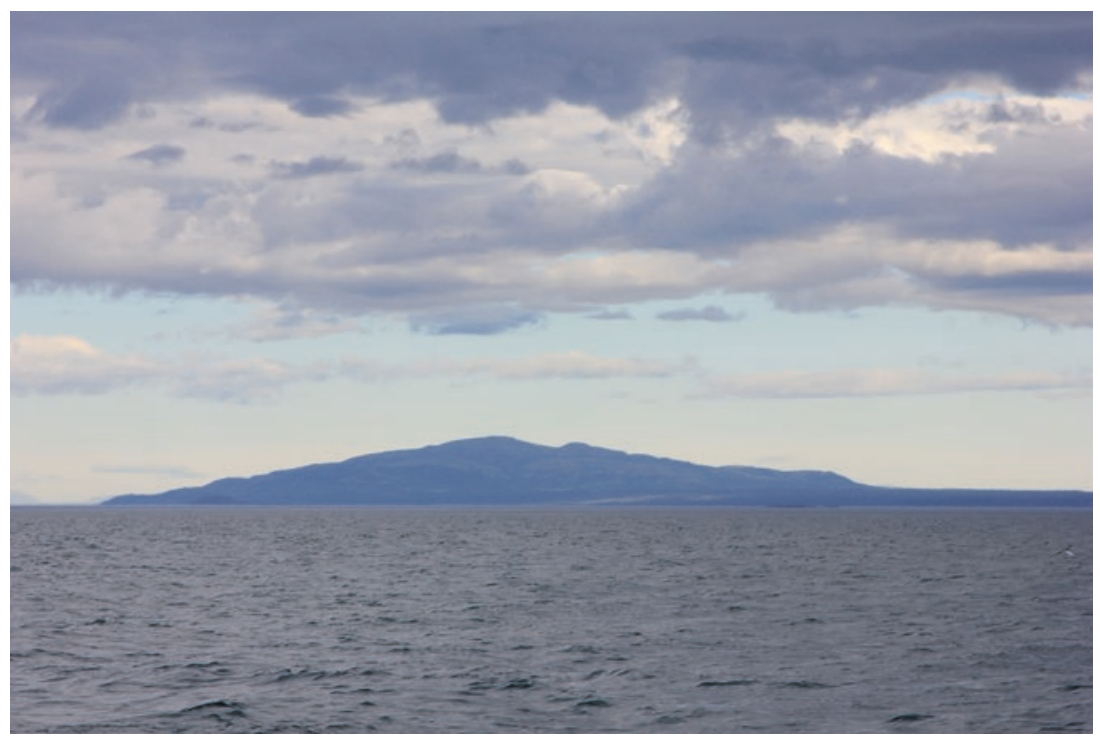

Fig. 3 Ingrirpak ("Big Mountain") viewed from a boat as the author and Iliamna Lake residents were crossing the southwest side of Nanvarkak ("Big Lake"), August 2018. (Photo: Yoko Kugo) 
Conversely, the Igiugig people (who reside on the southwest of Iliamna Lake) remember these boulders as Yuguat ("Human-like, Fake Humans") because of their shapes. The Igiugig people commonly traveled by land along the shore to Ingrirpak ("Big Mountain"), but rarely by water. Therefore, Igiugig people did not perceive the boulders as an important landmark. The boulders' two names, originating from different stories, indicate that environmental communications vary depending on the people's physical and spiritual connections with the landscape.

Oral narratives that guide people to live respectfully with nature are ubiquitous in many societies, including those in southwest Alaska. The oral tradition of An'gaqtar (Stone Lady), in Togiak, Alaska, exemplifies how the Yupiit perceive gift-offering to the boulder Stone Lady to help them maintain a healthy reciprocal relationship between the human and animal worlds, as well as between the living and spiritual worlds. According to the story, An'gaqtar, a Yup'ik woman, lost her husband and failed to find food for herself and her child in the harsh environment. As a result, An'gaqtar lost her mind and went insane due to starvation, and she turned into the boulder (Fienup-Riordan \& Rearden, 2012, pp. 48-50). Togiak Yupiit have rituals acknowledging An'gaqtar as their Ellam Yua (the Spirit of the Universe). They have practiced encircling An'gaqtar, moving in the sun's direction and giving offerings when they go by her. Fienup-Riordan and Rearden (2012) explain that the Togiak Yupiit understand An'gaqtar's facing east as meaning that she welcomes both the sunrise and new lives that support peoples' survival: animals, fish, plants, or even a newborn baby in the family (p. 58). The Togiak Yupiit ${ }^{6}$ beliefs surrounding An'gaqtar echo many Yup'ik creation stories about Raven creating rivers, mountains, and land for people and animals.

Iliamna Lake Yupiit do not recall how the boulders took the shape of Kass'armayiit. However, their practice of sharing food with the Kass'arnayiit resembles that of the Togiak Yupiit making offerings to An'gaqtar. Both rituals present living environmental communications that reinforce their relationships with their homelands and maintain their environment's well-being.

While the Yupiit remember the landscape along with their cultural practices and oral narratives, government surveyors have recorded the land features and shorelines by measuring latitude and distance. Government surveyors' not having recorded these boulders' names suggests that they

\footnotetext{
${ }^{6}$ In this case, the form "Yupiit" refers to the possessor.
} 
did not find them noteworthy. In their study of Sami place names, Cogos, Roué, and Roturier (2017) identify the government map publication process as "map making," which differs from "Sami mapping," wherein the Sami people use narratives to construct mental images of these places (p. 45). Narratives about Kass'arnayiit and An'gaqtar exemplify Cogos, Roué, and Roturier's (2017) notion of "micro-perspective," because these places hold regionally specific meanings to the residents. Place names can contribute critically to people's mental mapping as they travel, as in the case of Qikertarpak ("Big Island") and Ingrirpak ("Big Mountain") in the Iliamna Lake area. Government maps, or "map making," on the other hand, represent general environmental communication, presenting elevation, lengths of streams, and larger geographic features. Outsiders can use them to visualize potential natural resources around Iliamna Lake. In contrast, "Iliamna Lake Yup'ik mapping" exemplifies environmental communication from insider perspectives. Knowing how to travel safely on the large lake is crucial to Iliamna Lake residents for reaching their destinations and for harvesting seagull eggs, freshwater seals, and other resources around the lake.

\section{Discussion}

Narratives about place names and personal experiences at these places exemplify environmental communication from insider perspectives, because their interaction with the landscape comprises layers of memories from various times and accumulated residents' knowledge. Their conversations about place names and stories about these places convey and reinforce the significance of the place names to the people in the past and present. When Iliamna Lake Yup'ik Elders talked about place names, they typically started telling a story about where they grew up and where they used to travel with family from their settlement to another settlement. Their storytelling reflects environmental communication in connecting their family histories, way of life, and memories of the land features with their images of their landscape. Travel routes connecting the place names to one another demonstrate how the Yupiit lived, moved throughout the year harvesting food, and stayed at the fish camp on the shore of the river in the summer (Fienup-Riordan, 1990, p. 9). Ingold (2011) calls such geographic knowledge of the landscape a "web of knowledge," explaining that places are like knots in the web, and multiple travel routes connect those knots. For instance, some Yup'ik place names associated with fish 
camp, pike, and suckerfish in the Iliamna Lake area indicate that the Yupiit observed the abundance of fish and harvested them. A small group of Yupiit settled near Igcenaq because it lies on the shore of the river and is also within walking distance to small lakes where they can harvest pike.

Kawagley's explanation of the Yup'ik worldview and Basso's study of Western Apache place names show that Yupiit and Western Apache environmental communications are regionally specific and transmitted through dialogues and other practices. Iliamna Lake residents' understanding of some place names demonstrates their concerns about the environment. Residents refer not only to place names as physical landmarks, but they also strengthen spiritual and cultural connections to the land. Some Newhalen and Kokhanok residents believe that offering gifts to the boulders Kass'armayiit ("Those That Look Like Priests") will ensure that the Kass'armayiit watch over the peoples' safe passage. Residents remember an accident that happened at Igceñaq, whereas government land surveyors might simply record Igceńaq as "Rapids." Local knowledge embedded in the place name provides an environmental alert for the people as they move about the land. Senecah (2007) predicts that "collaborative processes will define the future of much environmental decision making, from local to global levels" (p. 28). Understanding place names and histories from insider perspectives can provide valuable insight in such decision making and promote the longevity of community prosperity.

The gift-offering practice reflects a core value among Alaska Natives. Sharing fish, meat, and plants with others and showing thankfulness to animals, landscape, and spiritual beings shows reciprocity and ensures future catches and safe travels. As Fienup-Riordan (2005) observes, being thankful to one another is "ubiquitous in Yup'ik daily life" (p. 59). This cultural ethic of offering food to Kass'armayiit is a mnemonic device, reminding the people of accidents that occurred near there in the past and ensuring safe journeys across the lake. Iliamna Lake people do not need scientific proof of the power of giving gifts to Kass'armayiit. Rather they do it because "it has been said"; their Elders have taught them to do so. According to Yup'ik professor Walkie Charles, a Yup'ik person does not own a narrative, story, or information about life in general. These stories and teachings are passed on from one person to another. In the old days, spoken Yugcetun was the medium of discourse; there was no way to write events or stories down on paper. Like many Indigenous languages, Yugcetun was initially a spoken, unwritten language until first contact by explorers, educators, and clergy (Barnum, 1901; Hinz, 1944; Nelson, 
1983). Storytelling and oral sharing of teachings and learning were the basis by which to make sense of the world around them for the survival of language and culture (Walkie Charles, personal communication, July 12, 2020). Stories containing cultural ethics are intertwined with place names and remind community members to be conscious of the environment.

When sharing physical information and histories of places, such place names perform an environmental communication role, in effect, participating in activities, shaping peoples' memories, and creating meanings within the landscape, as Meisner (n.d.) explains. Many Yup'ik place names require language skills to understand the deeper meanings of the names that represent an important part of Indigenous knowledge. Colonized and contemporary English names do not contain such cultural meanings, but they show the arrival of newcomers to the land, the modern economy, and the dominance of the English language through time. In using local place names and relating narratives about them, Iliamna Lake Yup'ik Elders share their wisdom and feelings of the land and tell their stories from their insider perspectives. In this way, recording and learning stories of Iliamna Lake Yup'ik place names decolonizes, and this sense of responsibility to the environment can help preserve biodiversity and sustainability.

Researchers can gain insight into environmental communication through ethnographic fieldwork and learning local usage of Indigenous place names with community residents. Iliamna Lake Yup'ik place names like Quarrumgvik ("Place for Sticklebacks"), Igcenaq ("Falling Place"), and Kass'armayiit ("Those That Look Like Priests") exemplify important roles in regionally specific environmental communication. I hope that the study of Iliamna Lake Yup'ik place names affirms the residents' cultural pride and that they continue to maintain their lifeways. Sharing place names and stories about these places is one way for the Iliamna Lake residents to communicate with others about the environment and to live in harmony with the world.

Acknowledgments I would like to thank the University of Alaska Fairbanks Center for Global Change and National Science Foundation (No. 1640812) for supporting my dissertation project. The Bristol Bay Native Corporation Education Foundation supported the Iliamna Lake communities' place names projects that I collaborated with on my dissertation. I also extend my thanks to the Iliamna Lake Place Names Committee and research participants who shared their time and stories with me. 


\section{REFERENCES}

Andrews, T. D., \& Zoe, J. B. (1997). The İdaà trail: Archaeology and the Dogrib culturallandscape, Northwest Territories, Canada.InG.P.Nicholas\&T.D.Andrews (Eds.), At a crossroads: Archaeology and First Peoples in Canada (pp. 160-177). Archaeology Press Department of Archaeology Simon Fraser University.

Barnum, F. S. J. (1901). Grammatical fundamentals of the Inuit language: As spoken by the Eskimo of the Western Coast of Alaska. Ginn \& Company, Publishers.

Basso, K. H. (1988). "Speaking with names": Language and landscape among the Western Apache. Cultural Anthropology, 3(2), 99-130.

Basso, K. H. (1996). Wisdom sits in places: Landscape and language among the Western Apache. University of New Mexico Press.

Battiste, M. A., \& Henderson, J. Y. (2000). Protecting Indigenous knowledge and heritage: A global challenge. Purich Pub.

Berkes, F., \& Folke, C. (1998). Linking social and ecological systems for resilience and sustainability. In F. Berkes, C. Folke, \& J. Colding (Eds.), Linking social and ecological systems: Management practices and social mechanisms for building resilience (pp. 1-25). Cambridge University Press.

Black, L. (2004). Russians in Alaska: 1732-1867. University of Alaska Fairbanks.

Coffing, M. (1991). Kwethluk subsistence: Contemporary land use patterns, wild resource harvest and use, and the subsistence economy of a Lower Kuskokwim River area community. Alaska Department of Fish and Game, Division of Subsistence.

Cogos, S., Roué, M., \& Roturier, S. (2017). Sami place names and maps: Transmitting knowledge of a cultural landscape in contemporary contexts. Arctic, Antarctic, and Alpine Research, 49(1), 43-51.

Collignon, B. (2004). It's a long way to the other geographers and geographic knowledges. GeoJournal, 60(4), 375-379.

Cox, R. (2007). Nature's “crisis disciplines": Does environmental communication have an ethical duty? Environmental Communication, 1(1), 5-20.

Cruikshank, J. (1990). Life lived like a story: Life stories of three Yukon Native Elders. University of Nebraska Press.

Evanoff, K. (2010). Dena'ina Etnena, a celebration: Voice of the Dena'ina. National Park Service Lake Clark National Park Preserve.

Fair, S. W. (1997). Inupiat naming and community history: The Tapqaq and Saniniq coasts near Shishmaref, Alaska. The Professional Geographer, $49(4), 466-480$.

Fienup-Riordan, A. (1990). Eskimo essays: Yup'ik lives and how we see them. Rutgers University Press.

Fienup-Riordan, A. (2005). Wise words of the Yup'ik People: We talk to you because we love you. University of Nebraska Press. 
Fienup-Riordan, A. (2017). Qanemcit Amllertut/Many stories to tell: Traditional tales and narratives from Southwest Alaska (A. Rearden \& M. Meade, Trans.). Fairbanks: University of Alaska Press.

Fienup-Riordan, A., \& Rearden, A. (2012). Ellavut/Our Yup'ik world and weather: Continuity and change on the Bering Sea coast. University of Washington Press.

Gumperz, J., \& Levinson, S. C. (1996). Introduction to Part I. In J. Gumperz \& S. C. Levinson (Eds.), Rethinking linguistic relativity (pp. 21-36). Cambridge University Press.

Harris, U. S. (2017). Engaging communities in environmental communication. Pacific Journalism Review, 23(1), 65-79.

Hinz, J. (1944). Grammar and vocabulary of the Eskimo language: As spoken by the Kuskokwim and Southwest Coast Eskimos of Alaska. The Society for Propagating the Gospel, the Moravian Church.

Holton, G. (2011). Differing conceptualizations of the same landscape. In D. M. Mark (Ed.), Landscape in language: Transdisciplinary perspectives (pp. 225-237). John Benjamins Publishing Company.

Hunn, E. S. (2006). Meeting of minds: How do we share our appreciation of traditional environmental knowledge? Royal Anthropological Institute, 143-160.

Igiugig Village Council. (2012). Our story, our people, our home. Igiugig Village Council.

Ingold, T. (2011). Being alive: Essays on movement, knowledge and description. Routledge.

Izmailov, G. G., \& Bocharov, D. I. (1785-1786). Map of the Alaska Peninsula.

Jacobson, S. A. (2012). Yup'ik Eskimo dictionary (Vols. 1 \& 2). Alaska Native Language Center, University of Alaska Fairbanks.

Kari, J. M. (1988). Some linguistic insights into Dena'ina prehistory. Alaska Anthropological Association Monograph Series, 4, 319-338.

Kari, J. M. (2013). Dena'ina topical dictionary. Alaska Native Language Center.

Kawagley, A. O. (2006). A Yupiaq worldview: A pathway to ecology and spirit (2nd ed.). Waveland Press.

Krauss, M., Holton, G., Kerr, J., \& West, C. T. (2011). Indigenous peoples and languages of Alaska [map]. Fairbanks: Alaska Native Language Center and UAA (University of Alaska Anchorage) Institute of Social and Economic Research. Retrieved from https://www.uaf.edu/anla/map

Kugo, Y. (2014). Subsistence practices of Iliamna Lake Villages: An investigation of dynamics of traditional and local ecological knowledge. M.A. thesis, University of Alaska Anchorage, Anchorage.

Kugo, Y., \& Iliamna Lake Place Names Committee. (2019). Place names of Nanvarpak, Nila Vena, Iliamna Lake [map]. Fairbanks: Alaska Native Language Center. 
Kluckhohn, C. (1961). Notes on Some Anthropological Aspects of Communication. American Anthropologist, 63(5), 895.

Meisner, M. (n.d.). Environmental communication: What it is and why it matters. International Environmental Communication Association. Retrieved June 17, 2018, from http://theieca.org/resources/environmentalcommunication-what-it-and-why-it-matters

Nadasdy, P. (2005). The anti-politics of TEK: The institutionalization of comanagement discourse and practice. Anthropologica, 47(2), 215-232.

Nelson, E. W. (1983). The Eskimo about Bering Strait. Vol. 18, pt. 1, Bureau of American Ethnology annual report for 1896-97. Smithsonian Institution Press. (Original work published 1899).

Nielsen, M., Kugo, Y., \& Iliamna Lake Place Names Committee. (2019). Place names of Iliamna Lake, Nanvarpak, Nila Vena [map]. Kokhanok: Kokhanok Village Council.

Orth, D. J. (1967). Dictionary of Alaska place names (revised 1971). Washington, DC: Government Printing Office.

Ray, D. J. (1971). Eskimo place-names in Bering Strait and vicinity. Names, $19(1), 1-33$.

Rearden, A., \& Fienup-Riordan, A. (2014). Nunamta Ellamta-llu Ayugucia: What our land and world are like: Lower Yukon history and oral traditions. Alaska Native Language Center.

Rosaldo, R. (1980). Ilongot headhunting, 1883-1974: A study in society and history. Stanford University Press.

Ross, A., Sherman, R., Snodgrass, J. G., \& Delcore, H. D. (2011). Indigenous peoples and the collaborative stewardship of nature: Knowledge binds and institutional conflicts. Left Coast Press.

Salmon, A. (2014). The Kukaklek Reindeer Station. Alaska Journal of Anthropology, $12(2), 46-51$.

Senecah, S. L. (2007). Response to Cox: Impetus, mission, and future of the environmental communication commission/division: Are we still on track? Were we ever? Environmental Communication, 1(1), 21-33.

Smith, L. T. (1999). Decolonizing methodologies: Research and indigenous peoples. Zed Books.

Stewart, G. R. (1954). A classification of place names. Names: A Journal of Onomastics, 2(1), 1-13.

Stoffle, R. W., Arnold, R., \& Bulletts, A. (2016). Talking with nature: Southern Paiute epistemology and the double hermeneutic with a living planet. In G. Tully \& M. Ridges (Eds.), Collaborative heritage management (pp. 75-99). Gorgias Press.

Stoffle, R. W., Halmo, D. B., \& Austin, D. E. (1997). Cultural Landscapes and Traditional Cultural Properties: A Southern Paiute View of the Grand Canyon and Colorado River. American Indian Quarterly, 21(2), 229-249. 
Thornton, T. F. (2008). Being and place among the Tlingit. University of Washington Press.

Townsend, B. J. (1973). Ethnoarchaeology in nineteenth century southern and western Alaska: An interpretive model. Ethnohistory, 20(4), 393-412.

VanStone, J. W. (1988). Russian exploration in Southwest Alaska: The travel journals of Petr Korsakovskiy (1818) and Ivan Ya. Vasilev (1829). University of Alaska Press.

Waterman, T. T. (1922). The geographical names used by the Indians of the Pacific Coast. Geographical Review, 12(2), 175-194.

Wrangell, F. P. V., \& VanStone, J. W. (1970). The inhabitants of the Northwest Coast of America. Arctic Anthropology, 6(2), 5-20.

Open Access This chapter is licensed under the terms of the Creative Commons Attribution 4.0 International License (http://creativecommons.org/licenses/ by $/ 4.0 /$ ), which permits use, sharing, adaptation, distribution and reproduction in any medium or format, as long as you give appropriate credit to the original author(s) and the source, provide a link to the Creative Commons licence and indicate if changes were made.

The images or other third party material in this chapter are included in the chapter's Creative Commons licence, unless indicated otherwise in a credit line to the material. If material is not included in the chapter's Creative Commons licence and your intended use is not permitted by statutory regulation or exceeds the permitted use, you will need to obtain permission directly from the copyright holder.

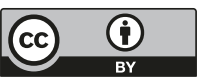

